\title{
Clinical benefits and adverse effects of siwak (S. persica) use on periodontal health: a scoping review of literature
}

\author{
Haslinda Ramli ${ }^{1,2}$, Tuti Ningseh Mohd-Dom ${ }^{1 *}$ and Shahida Mohd-Said ${ }^{3}$
}

\begin{abstract}
Background: Siwak is a chewing stick used as an oral hygiene aid associated with Muslim communities across the globe since more than 1500 years ago. Used either exclusively or in conjunction with a regular toothbrush, there is evidence supporting its clinical effectiveness in plaque control, but adverse effects on periodontal health remains inconclusive.
\end{abstract}

Objective: This study aims to systematically review the wide range of data and literatures related to siwak practice and its effect on periodontal health.

Method: The review was conducted based on scoping review techniques, searching literature in EBSCOHOST, PubMed, SCOPUS and Google scholar databases using the following search terms: "siwak' or 'miswak' or 'chewing stick" for intervention, and "periodontium or 'periodontal' or 'periodontal health' or 'periodontal disease" for outcome. Articles published between January 1990 to March 2021 and written in English language were included.

Results: A total of 721 articles collected from the search and 21 of them were eligible for the final analysis. Results of this study was described based on clinical and antibacterial reporting of siwak, method of siwak practice and its adverse effect on oral health. Siwak was found effective at removing dental plaque and improving periodontal health over time although its effect on subgingival microbiota was inconclusive. Presence of gingival recession and clinical attachment loss were much more commonly reported in siwak users, attributable to variations in the methods employed for tooth cleaning using the siwak.

Conclusion: There is substantial evidence that the lack of standardised reporting for effective siwak use may have resulted in contradictory findings about its oral hygiene benefits and adverse effects. As such, future work on safe and effective siwak practice is to be advocated among its users.

Keywords: Chewing stick, Siwak, Salvadora persica, Gingivitis, Plaque, Gingival recession

\section{Introduction}

Rationale

Siwak is a chewing stick obtained from stem, twig and root of a tree, name Arak (Salvadora persica) and used

\footnotetext{
*Correspondence: tutinin@ukm.edu.my

1 Department of Family Oral Health, Faculty of Dentistry, Universiti

Kebangsaan Malaysia, Jalan Raja Muda Abdul Aziz, 50300 Kuala Lumpur,

Malaysia

Full list of author information is available at the end of the article
}

for teeth and oral cleaning. This chewing stick is usually prepared at an average of $1.0 \mathrm{~cm}$ in diameter and $15 \mathrm{~cm}$ in length to ease its insertion into the mouth and placement on tooth surfaces. Its middle part contains ample phloem and has a spongy texture. After soaking it in water for at least one or two minutes, the stick will become more chewable, hence it becomes easier to remove it while crushing the end portion of the bark, causing it to have a brush-like appearance and ready to use [1,2]. 
While siwak had been used by various civilizations [3], for the Arabs it was only during the Islamic period that personal hygiene was further emphasised as part of religious obedience, including the use of siwak as a tool for oral hygiene [4]. As a display of obedience to religious advice, groups of Islamic movement (Jama'ah tabligh) would also constantly have siwak in their pocket $[4,5]$. Today, the siwak practice continues and is typically recognised as a cultural identity among Muslim communities.

There are varying reports of siwak users in the developing country and from different regions of Saudi Arabia, Africa, Iran, India and Malaysia [6-11]. The prevalence of adults who use siwak in Cameroon was found to be high (85\%) [9], while in Aseer, Saudi Arabia only about half $(52.7 \%)$ of the adults are reported to use siwak either as a toothbrush replacement, or together with toothbrush. Generally, the adjunctive use of siwak was found to be of personal preference [6] including the majority (73\%) of jamaáh tabligh congregating at a mosque in Kuala Lumpur, Malaysia [12] where the first mass outbreak of COVID-19 was reported in that country.

At present times where the use of the standard toothbrush is widespread, the cost of siwak may be considered cheaper than the toothbrush especially in countries where its plant source is cultivated locally. Such example is in Uganda, where the two most common plants used as chewing stick are Rhus vulgaris Meikle and Landa trifolia L [13]. The plant sources vary around the world, namely in India, the siwak that is widely used is from Neem (Azadirachtaindica); in West Africa the plant source is lime tree (Citrus aurantafolia) and orange tree citrus (Citrus sinensis); in other parts of Africa it is Senna (Cassia vennea), and in the Middle East it is Arak (Salvadora persica) [14]. Moreover, while neem is a native plant in India, siwak from its source is also available in Indonesia, Malaysia, Australia, Sri Langka, Burma, Pakistan and Africa [15]. Besides its comparatively low cost to produce, convenient access to the source is another factor promoting the use of siwak.

Apart from these reasons, another main reason people choose siwak was because of religious beliefs $[6,9$, $12,16]$. That being acknowledged, only $32.6 \%$ of the general Muslim population in Malaysia reported to have had experience of using siwak although almost all study participants were aware that siwak use is a sunnah (customary) of the Prophet Muhammad, peace be upon him [17]. Additionally, the method and practice of siwak by the Prophet (PBUH) is generally unknown. Nevertheless, the benefits of siwak on oral health care are acknowledged [17] and for this reason as well as religious beliefs, the use of siwak becomes a. continued practice in muslim communities [16].

\section{Aims}

This study aims to systematically review the literatures on the nature, and extent of siwak use and to identify the gap of knowledge, in relation to the methods of siwak practice. Specifically, this present paper is focused on the clinical benefits of siwak, and its adverse effects to periodontal health in relation to the nature and method of siwak practice.

\section{Methodology \\ Scoping review design}

This review process was undertaken based on an established scoping review technique that follows a framework proposed by Joanna Briggs Institute (JBI) and guided by the updated methodology of the Preferred Reporting Items for Systematic Reviews and MetaAnalyses extension for Scoping Reviews (the PRISMAScR) $[18,19]$. This technique was chosen to enable the exploration of broader research questions and interpret materials from various range of evidences $[18,20]$. Data from different types of studies and methodologies that are relevant to the intervention/concept and outcome/ context of the topic were processed.

\section{Review registration}

The review title has been registered with Open Science Framework (OSF registration number: osf-registrations-xzhsk-v1).

\section{Information sources}

The overall review process involved systematic searching and screening of literature, extraction of data from the articles and synthesis of findings. The terms or keywords of "siwak or miswak or chewing stick" correspond to the intervention and "periodontium or periodontal or periodontal health or periodontal disease" for outcome, were used in the search process. These keywords were identified from the initial scoping of the literature and keywords. The search engines in this review were EBSCOHOST (Dentistry and Oral Sciences), PubMed, SCOPUS and Google scholar databases. The search article was filtered for academic journals, human studies, written in English language and published within year 1990 to 2021. Additional relevant publications were found through a manual search of the reference lists of the included studies. The rationale and detail of search string may be found in Table 1.

\section{Selection of sources of evidence and eligibility criteria}

The screening was conducted independently by two researchers, which agreed on, i) if abstracts were not present, results and conclusion sections were used 


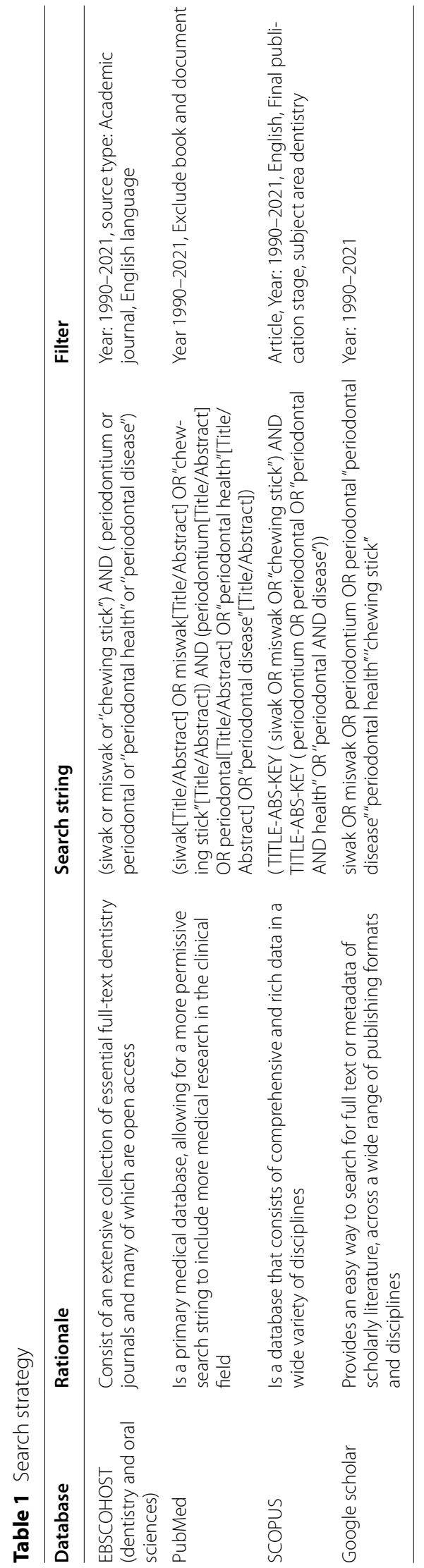


to determine relevance, and ii) studies that aimed to assess the oral hygiene practice in their population, were included for the following eligibility assessment, because of the possibility that siwak is an option of oral hygiene tool. Accordingly, studies which reported on the effect of siwak on periodontal health and described how tooth cleaning using siwak was practiced were included for full paper review. The assessment of eligibility was made based on the inclusion and exclusion criteria. Any disagreement between two researchers, were resolved upon consensus meeting with a third researcher. The rationale of inclusion and exclusion criteria was set out in Table 2 and expand on "PCC" mnemonic (population, concept and context) as recommended.

\section{Data charting process and data items}

Extraction and synthesis of information from the included articles was summarized and presented in tables organized under descriptive, methodological, and thematic categories, correspond to the objective and questions of the review [18, 20]. To make reporting easier, a charting table was created during the protocol stage to summarise and record the information according to description of author, reference, and findings. The table was updated throughout the review stage. The data extraction using charting form was piloted with two researchers on three studies. The researchers refined the data to ensure that they were aligned with the research question. A critical evaluation is made on literatures associated with the effects of siwak practice on periodontal health among adults and aimed to answer the following review questions:

\section{What are the clinical benefits of siwak on adult} oral health?

2. What are the common methods and practices of siwak?

3. Does method and siwak practice contribute to the adverse effect to periodontal health?

The potential data are considered based on the method of siwak brushing and practice and its effect on periodontal health. Although it physical features is different with conventional toothbrush, the users apply similar technique of toothbrushing $[3,16]$. Because of that, the efficiency of siwak in removal of plaque, whether supragingival or subgingival may be questioned. Alternatively, varying frequency of siwak use was applied throughout the day [16]. The outcome of toothbrushing also depending on frequency and duration of toothbrushing. However, excessive tooth brushing might cause soft tissue and hard tissue injury such as gingival recession, abrasion and tooth wear [24].

\section{Result \\ Synthesis of result}

A total of 721 articles were identified from the initial search, then 65 replicates and 62 abstract conferences were removed and lastly 594 were screened based on the titles and abstracts with reference to the inclusion and exclusion criteria as illustrated in Table 2. Following the screening process, more than half of the articles were further excluded due to the following factors: irrelevant to

Table 2 Inclusion and exclusion criteria

\begin{tabular}{|c|c|}
\hline Criterion & Rationale for inclusion and exclusion \\
\hline $\begin{array}{l}\text { Population: } \\
\text { Adult }\end{array}$ & $\begin{array}{l}\text { An adult is person who has reached the age of maturity or adulthood [67]. The use of siwak as } \\
\text { an alternative oral hygiene tool among adult who are physically and mentally fit, is considered } \\
\text { independent behaviour, compared to children. The adults wearing fixed orthodontic appliance are } \\
\text { excluded to minimise the effects of plaque-retentive factors and ease toothbrushing [21] }\end{array}$ \\
\hline $\begin{array}{l}\text { Concept: } \\
\text { Effect of siwak on periodontal health } \\
\text { Method and practice of siwak }\end{array}$ & $\begin{array}{l}\text { The World Health Organization (WHO) recognises siwak as an alternate oral hygiene, but more } \\
\text { research is needed [22]. It is derived from a common plant and comes in different diameter and } \\
\text { length, as well as having distinct characteristics from toothbrushes [3]. Thus, the method and siwak } \\
\text { practice may differ from the toothbrush and may have favourable and/or adverse effect on oral } \\
\text { health, particularly periodontium. According to Shah et al. [23] traditional oral hygiene practises } \\
\text { can harm the soft and hard tissues of the mouth }\end{array}$ \\
\hline
\end{tabular}

Context:

Clinical benefit and adverse effect of siwak 
the topic (314), did not fulfil the inclusion intervention or outcome (122), article published in other languages (9) and were in the form of thesis or dissertation (41). At the end of the screening, a total of 87 articles were deemed relevant, plus two additional articles which were handsearched from reference lists of included studies. Finally, a total of 21 articles were included for this report and they comprised of original studies involving adult populations from nine randomised-controlled trial (RCT); ten cross-sectional studies; and two case reports. The results from this multi-stage systematic sorting process were summarised and presented in Fig. 1.

\section{Identification of studies via databases and registers}
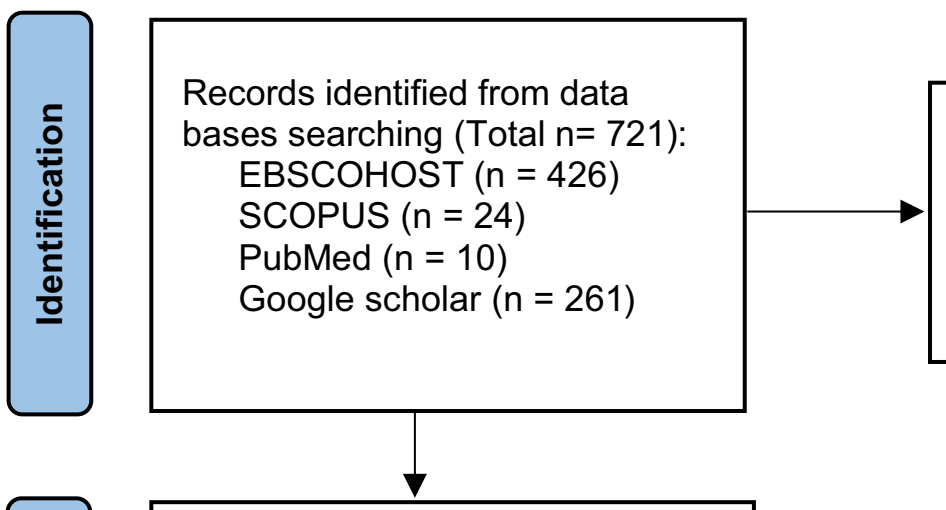

Records removed before screening:

Duplicate records removed $(n=65)$

Records removed for other reasons:

Abstract proceeding $(n=62)$

Records after duplicates and abstract proceeding removed $(n=594)$
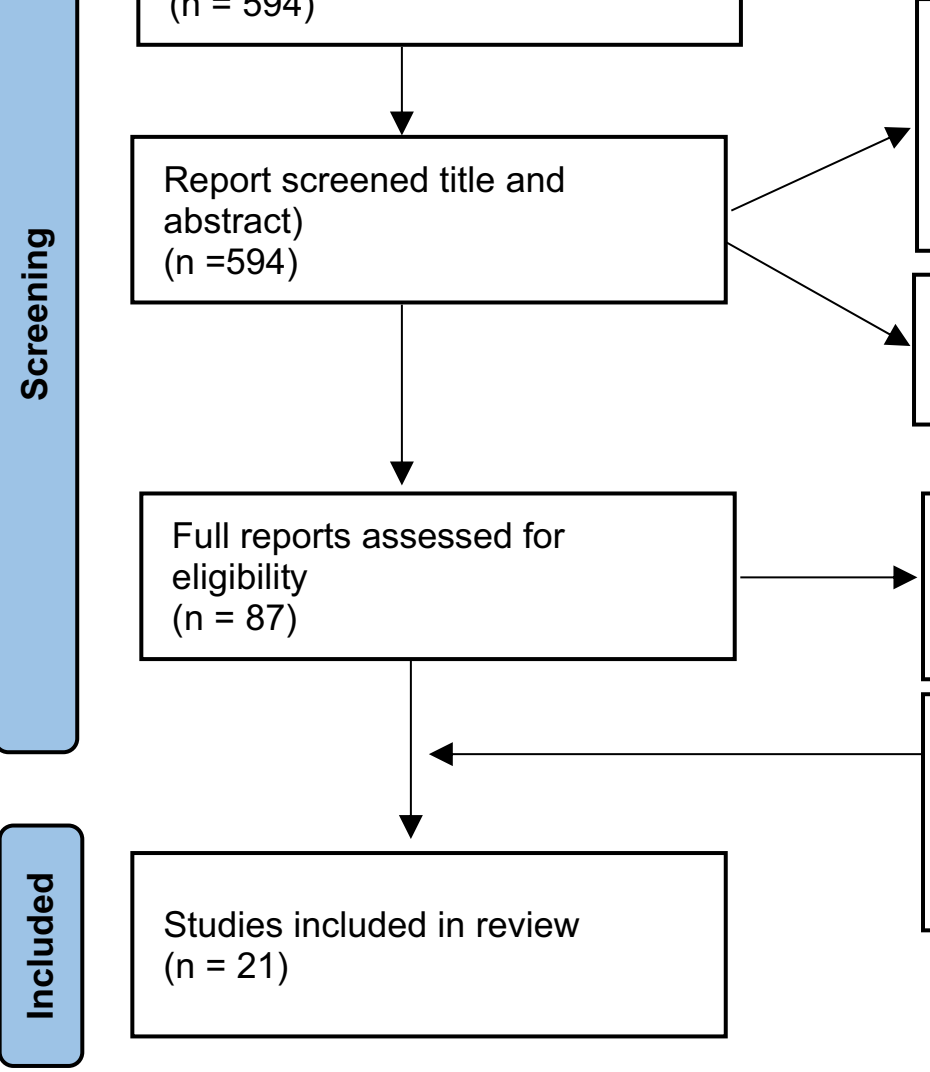

Records excluded:

Not related to the topic $(n=314)$

Thesis/dissertation or book $(n=41)$

Other languages $(n=9)$

Not fulfill inclusion criteria $(n=122)$

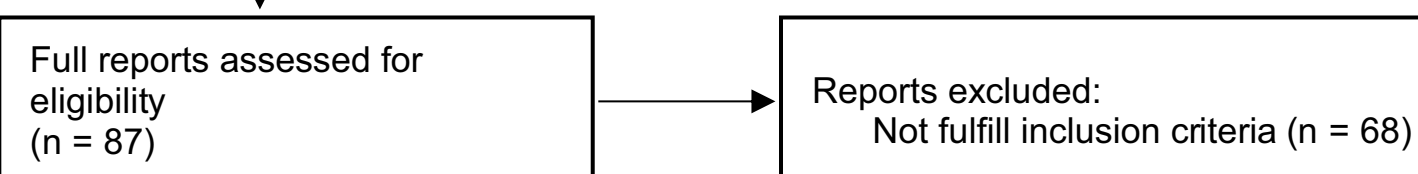

$(n=21)$

Fig. 1 Flow-chart of selection of studies for the review 
The goal of this scoping review was to gather the findings and present an overview of the research rather than to assess the quality of the individual studies. As a result, our overall assessment was narrative rather than quantitative. The descriptive result was summarised with regards to the effect of siwak on oral health and presented according to the following themes: (1) clinical effect of siwak on periodontal health, (2) antibacterial effect of siwak, and (3) method of siwak practice and adverse effect.

\section{Clinical effects of siwak on periodontal health}

Descriptions of studies reporting clinical effects of siwak on oral health are summarised in Table 3. Based on the observational, analytical and cross-sectional studies, the effect of siwak on plaque removal and improvement of gingival health was comparable to that of using toothbrush, whether its use was exclusive or adjunctively [26]. The mean plaque score of siwak user was comparable to toothbrush users, even if used exclusively [27]. Moreover, the mean probing pocket depth (PPD) and gingivitis score were found lower in siwak users compared to toothbrush users [28]. Although PPD and clinical attachment loss (CAL) were comparable to toothbrush, the mean plaque score and bleeding score were significant lower in siwak user, [29]. Despite the lower number of sextants with gingival bleeding and probing pocket depth $\geq 4 \mathrm{~mm}$, there were higher sites of $C A L \geq 4 \mathrm{~mm}$ noted in siwak users [30]. Additionally, the mean PPD and CAL were greater, and more sites with gingival recession (REC), when siwak used adjunctively [26, 31]. Inversely, recent works by Ramadan \& Alshenqiti discovered significant lower means of PPD, CAL and plaque score, in similar siwak application, compared to toothbrush [32].

According to clinical studies employing cross-over randomised controlled trials (Table 4), significant reductions of plaque and gingival scores were observed among siwak users compared to the toothbrush users [34, 35]. However, its effect on improvement of gingival health was comparable with that of toothbrushing [36]. Furthermore, Bhambal et. al. found that siwak was equally effective to reduce plaque as well as improving gingival health [37]. It was observed that there were significantly greater reductions of plaque score and gingivitis, when siwak was used as an adjunct to the toothbrush [38-40].

\section{Antibacterial effect of siwak}

There were four studies which reported the antibacterial effects of siwak (Table 5) from their randomised controlled trials which compared exclusive use of siwak with toothbrushing and its effect on the quantity of subgingival microbiota [39, 42-44]. There was significantly higher quantity of Aggregatibacter actinomycetemcomitans, Veillonella parvula, Actinomyces israelii,

Table 3 Clinical effect of siwak on periodontal health: cross sectional study

\begin{tabular}{|c|c|c|c|c|}
\hline References & $\begin{array}{l}\text { Study groups } \\
\text { ( } \mathrm{n}=\text { sample } \\
\text { size) }\end{array}$ & Siwak application & Periodontal parameter & Finding \\
\hline Eid et al. [26] & $\begin{array}{l}\text { TB }(n=94) \\
S(n=68) \\
\text { S\&TB }(n=74)\end{array}$ & $\begin{array}{l}\text { Exclusive } \\
\text { Adjunctive }\end{array}$ & $P I, G I, P P D, C A L, R E C$ & Mean plaque score and gingivitis score was comparable with TB \\
\hline Khawaja et. al. [33] & $\begin{array}{l}\text { TB }(n=30) \\
S(n=30)\end{array}$ & Exclusive & $\mathrm{Pl}, \mathrm{Gl}$ & \\
\hline Batwa et al. [27] & $\begin{array}{l}\text { TB }(n=29) \\
S(n=17)\end{array}$ & Exclusive & $\mathrm{PI}$ & Mean plaque score was comparable with TB \\
\hline Shetty et al. [28] & $\begin{array}{l}\text { TB }(n=216) \\
S(n=144) \\
\operatorname{S\& TB}(n=168)\end{array}$ & Exclusive & OHI-S, GI, PPD, REC & $\begin{array}{l}\text { Mean plaque scores comparable with TB } \\
\text { Significant lower gingivitis score and probing pocket depth } \\
\text { Significant higher gingival recession }\end{array}$ \\
\hline Al-Sinaidi [29] & $\begin{array}{l}\text { TB }(n=74) \\
S(n=113)\end{array}$ & Exclusive & $\mathrm{PI}, \mathrm{BOP}, \mathrm{PPD}, \mathrm{CAL}$ & $\begin{array}{l}\text { Significant lower mean plaque score and bleeding score } \\
\text { Mean PPD and CAL were comparable with TB }\end{array}$ \\
\hline Darout et al. [30] & $\begin{array}{l}\text { TB }(n=104) \\
S(n=109)\end{array}$ & Exclusive & CPI: BOP, PPD, Calculus & $\begin{array}{l}\text { Lower no. sextant of gingival bleeding, probing pocket } \\
\text { depth } \geq 4 \mathrm{~mm} \\
\text { Higher number of sextants with } \geq 4 \mathrm{~mm} \mathrm{CAL}\end{array}$ \\
\hline Eid et. al $[26,31]$ & $\begin{array}{l}\text { TB }(n=94) \\
S(n=68) \\
\text { S\&TB }(n=74)\end{array}$ & Adjunctive & PI, GI, PPD, CAL, REC & $\begin{array}{l}\text { Significant higher mean PPD and CAL } \\
\text { Higher percentage sites with REC }\end{array}$ \\
\hline Ramadan et al. [32] & $\begin{array}{l}\operatorname{TB}(n=78) \\
S(n=36) \\
\operatorname{S\& TB}(n=36)\end{array}$ & Adjunctive & $\mathrm{PI}, \mathrm{PPD}, \mathrm{CAL}$ & Lower mean plaque score, PPD and CAL, than TB \\
\hline
\end{tabular}

$\mathrm{OHI}$-S, simplified oral hygiene index; PI, plaque index; Gl, gingivitis index; BOP, bleeding on probing; PPD, probing pocket depth; CAL, clinical attachment loss; REC, gingival recession; S, siwak; TB, toothbrush 
Table 4 Clinical effect of siwak on periodontal health: Randomised controlled trial RCT)

\begin{tabular}{|c|c|c|c|c|c|}
\hline References & Study design & $\begin{array}{l}\text { Study group } \\
(\mathrm{n}=\text { sample } \\
\text { size })\end{array}$ & Siwak application & Periodontal parameter & Finding \\
\hline Gazi et al. [41] & Cross over & $\begin{array}{l}\text { TB }(n=10) \\
S(n=10)\end{array}$ & Exclusive & $\mathrm{Pl}, \mathrm{Gl}$ & $\begin{array}{l}\text { Significantly reduced mean plaque and } \\
\text { gingivitis scores }\end{array}$ \\
\hline Al-Otaibi et al. [25] & Cross over & $\begin{array}{l}\text { TB }(n=15) \\
S(n=15)\end{array}$ & Exclusive & PI, Plaque-stained surface, Gl & \\
\hline Baeshen et al. [35] & Cross over & $\begin{array}{l}\text { TB }(n=15) \\
S(n=15)\end{array}$ & Exclusive & $\mathrm{PI}$ & $\begin{array}{l}\text { Percentage of plaque was comparable with } \\
\text { TB }\end{array}$ \\
\hline Bhambal et al. [37] & Cross over & $\begin{array}{l}\text { TB }(n=30) \\
S(n=30)\end{array}$ & Exclusive & $\mathrm{Pl}, \mathrm{Gl}$ & $\begin{array}{l}\text { Reduced mean plaque and gingivitis scores, } \\
\text { but no significant difference with TB }\end{array}$ \\
\hline Malik et al. [36] & Parallel & $\begin{array}{l}\text { TB }(n=25) \\
S(n=25)\end{array}$ & Exclusive & $\mathrm{Pl}, \mathrm{Gl}$ & $\begin{array}{l}\text { Significantly reduced plaque } \\
\text { Comparable with TB in improving gingival } \\
\text { health }\end{array}$ \\
\hline Patel et al. [38] & Parallel & $\begin{array}{l}\operatorname{TB}(n=10) \\
S(n=10) \\
S \& \operatorname{TB}(n=10)\end{array}$ & Adjunctive & PI, Plaque-stained surface, Gl & $\begin{array}{l}\text { Significantly greater reduction of plaque and } \\
\text { gingivitis score }\end{array}$ \\
\hline Othman et al. [40] & Parallel & $\begin{array}{l}T B(n=10) \\
S(n=10) \\
S \& T B(n=10)\end{array}$ & Adjunctive & $\mathrm{Pl}, \mathrm{Gl}$ & $\begin{array}{l}\text { Significantly greater reduction of plaque and } \\
\text { gingivitis score }\end{array}$ \\
\hline Rifaey et al. [39] & Cross over & $\begin{array}{l}\operatorname{TB}(n=10) \\
S \& \operatorname{TB}(n=10)\end{array}$ & Adjunctive & $\mathrm{Pl}, \mathrm{Gl}, \mathrm{BOP}$ & $\begin{array}{l}\text { Significantly greater reduction of plaque and } \\
\text { gingivitis score }\end{array}$ \\
\hline
\end{tabular}

$\mathrm{PI}$, plaque index; $\mathrm{Gl}$, gingivitis index; $\mathrm{BOP}$, bleeding on probing; TB, toothbrush; S, siwak

Table 5 Antibacterial effect of siwak

\begin{tabular}{|c|c|c|c|c|c|}
\hline References & Study type & Siwak application & Sample collection & Microbiological assessment & Finding \\
\hline $\begin{array}{l}\text { Darout et al. [44] and } \\
\text { Darout and Skaug } \\
\text { [42] }\end{array}$ & Cross sectional & Exclusive & Subgingival plaque & $\begin{array}{l}\text { Whole DNA probe and check- } \\
\text { board DNA-DNA hybridisation }\end{array}$ & $\begin{array}{l}\text { Significantly higher prevalence } \\
\text { of Aggregatibacter actinomy- } \\
\text { cetemcomitans, Veillonella } \\
\text { parvula, Actinomyces israelii, } \\
\text { Capnocytophaga gingivalis and } \\
\text { Streptococcus intermedius }\end{array}$ \\
\hline Al-Otaibi et al. [34] & $\mathrm{RCT}$ & Exclusive & Subgingival plaque & $\begin{array}{l}\text { Whole DNA probe and check- } \\
\text { board DNA-DNA hybridisation }\end{array}$ & $\begin{array}{l}\text { Reduced number of A. actinomy- } \\
\text { ctemcomitans }\end{array}$ \\
\hline Rifaey et al. [39] & $\mathrm{RCT}$ & Adjunctive & Supragingival plaque & Quantitative real-time PCR & $\begin{array}{l}\text { No significant difference of } A \text {. } \\
\text { actinomycetemcomitans and } \\
\text { Streptococcus Mutan }\end{array}$ \\
\hline
\end{tabular}

$\mathrm{RCT}$, randomised controlled trial; DNA, deoxyribonucleic acid

Capnocytophaga gingivalis and Streptococcus intermedius in the siwak groups [42] compared to toothbrushing groups. However, a greater reduction in the number of $A$. actinomyctemcomitans was found in the subgingival plaque of siwak user compared to toothbrush [34]. In contrast, there was no significant difference of A. actinomycetemcomitans and Streptococcus Mutan, in supragingival plaque, between these groups [39].

\section{Method of siwak practice and adverse effects}

Majority of the studies included in this review did not report on the method or technique of siwak used as a tooth cleaning tool and had no description on the frequency and duration of the daily siwak practice.
Nonetheless, in studies that mentioned tooth cleaning methods, descriptions such as siwak being applied in either vertical direction or combination of horizontal directions were frequently cited, as shown in Table $6[26$, $31,35,45]$.

Severe gingival recession and tooth surface loss was discovered on the buccal and lingual teeth of a woman that used siwak for toothbrushing in vertical and horizontal directions [45]. The same method of tooth cleaning was applied in a clinical trial and signs of traumatic lesions were reported on gingival tissue [35]. Without reporting the method of siwak use and practice, Saleh et al. discovered gingival recession on labial surface of anterior teeth of $65 \%$ of jamaah tabligh [5]. 
Table 6 Method of siwak practice and adverse effect

\begin{tabular}{|c|c|c|c|c|}
\hline References & Study type & Method & $\begin{array}{l}\text { Practice (frequency and } \\
\text { duration) }\end{array}$ & Adverse effect \\
\hline Eid et al. [26, 31] & Cross sectional & Vertical & $1-5$ times/day & $\begin{array}{l}\text { Higher mean CAL and REC on mid- } \\
\text { buccal surface }\end{array}$ \\
\hline Darout et al. [30] & & Not reported & At least once daily & $\begin{array}{l}\text { Higher number of sextants } \\
\text { with } \geq 4 \mathrm{~mm} \mathrm{CAL}\end{array}$ \\
\hline Baeshen et al. [35] & $\mathrm{RCT}$ & Vertical and horizontal & 2 times/day, 5 min & Traumatic lesion on gingival tissue \\
\hline Al-Otaibi et al. $[25,34]$ & & Not reported & 5 times/day & Not reported \\
\hline Bhambal et al. [37] & & Not reported & 2 times/day & Not reported \\
\hline Patel et al. [38] & & Not reported & 3 times/day & Not reported \\
\hline Malik et al. [36] & & Not reported & 2 times/day, $2-5 \min$ & Not reported \\
\hline Othman et al. [40] & & Not reported & 2 times/day, at least 2 min & Not reported \\
\hline Rifaey et al. [39] & & Not reported & 2 times/day & Not reported \\
\hline Karia and Kelleher [45] & Case report & $\begin{array}{l}\text { Scrubbing motion on every tooth } \\
\text { surface, horizontal on buccal and } \\
\text { vertical on lingual }\end{array}$ & Not reported & $\begin{array}{l}\text { Severe cervical tooth surface loss } \\
\text { (buccal and lingual) and generalised } \\
\text { gingival recession }\end{array}$ \\
\hline Saleh et al. [5] & & Not reported & Not reported & Gingival recession \\
\hline
\end{tabular}

$\mathrm{RCT}$, randomised controlled trial

The description of siwak practice is made based on the frequency and duration of its daily use as summarised and listed in Table 6. The frequency of siwak use was stated within the range of one to five times in a day, and duration of toothbrushing last was at least two minutes. The frequency of five times daily and brushing in vertical direction was practised by siwak users, and resulted in clinical attachment loss and gingival recession [31]. Another observation among siwak users showed that although the frequency of use was at least once daily, there were more sites with clinical attachment loss of at least $4 \mathrm{~mm}$ [30]. The frequency of siwak use in the design of the clinical trials was between two to five times [25, 34, 37-39]. Other clinical trials reported the duration of siwak use to be between two to five minutes $[35,36,40]$.

\section{Discussion}

The Salvadora persica tree is considered as the main source of siwak in many countries. It is commonly found in Algeria, Egypt, India, Nigeria, Pakistan, Saudi Arabia, Sri Lanka, Uganda and Zimbabwe [46]. With regards to research done on siwak, the same source of siwak is also utilised in most in-vivo and in-vitro studies. Siwak from S.persica tree is the most common use for oral hygiene. The siwak practice started at young age population in countries such as India, Sudan, Tanzania, Saudi Arabia and Yemen [8, 10, 47-50]. This early exposure to siwak use explains why the prevalence of siwak use increases in young adult and highest in elderly as its use is likely to have become a habit from a young age and persist till old $[43,51,52]$.
Our review found that the main reasons of choosing siwak as an oral hygiene tool is likely to be due to religous beliefs $[6,9,16,43]$. In addition, the specific features of siwak in its natural form had been claimed to ease its application on the teeth; specifically its small head may facilitate better access to the posterior teeth. Moreover, the availability of the source of supply which is direct from a tree contributes to its low cost. All these factors promote the use of siwak for oral hygiene care [9]. Almost $85 \%$ of users reported to feel fresh and whiter teeth after the use of siwak [6]. Other users noticed the absence of gum bleeding and improved oral health, and perceived oral health benefit of siwak use, and these factors has influenced them to choose siwak over toothbrush [16].

\section{The clinical benefits of siwak on periodontal health}

The oral hygiene and gingival health of siwak users were found to be comparable to tooth brush users [26, 31, 33, 37]. Moreover, significant antiplaque and antigingivitis effects were discovered in the randomised controlled clinical trials and analysed in this review [25, 34-36, 41]. Equally important is the finding that significantly greater reductions of plaque and gingivitis scores were observed when siwak was used as an adjunct to the toothbrush [38, 39]. These observations indicate that siwak was either equally effective as toothbrush for mechanical plaque removal or in some studies its use was seen to be superior. These positive benefits support the World Health Organisation (WHO) recommendation on the use of siwak as an alternative measure to the toothbrush for oral hygiene care [22]. Furthermore, siwak exhibits a similar 
impact as the use of stannous fluoride in the reduction of dental plaque and gingivitis [53].

Gingivitis is an early stage of periodontal disease, and if not treated it may progress to periodontitis causing destruction to the tooth supporting structure and at worst will result in tooth loss. Moreover, there is strong evidence that associate periodontal disease with systemic disease, such as diabetes. This condition may complicate the treatment, increase financial burden and have a negative impact on quality of life [54]. Systematic maintenance of bacteria plaque removal is crucial to prevent reinfection and further bone loss, suggesting long-term dependency on dental visits [55].

It is now known that for the success of periodontal care, it is best that management is personalised according to their genomic and clinical findings and therefore oral hygiene care is still the cornerstone of periodontal disease prevention. As such, self-performed mechanical plaque removal (SPMPR) is important to improve the periodontal health and prevent primary periodontitis (Needleman et al., 2015). The mechanical effect of siwak seems proven to distrupt the bacterial plaque and improved the periodontal health as shown by the lower gingivitis score, probing pocket depth and fewer sites of pocket $\geq 4 \mathrm{~mm}$, found in siwak users $[28,30]$. However, the effect of siwak on subgingival plaque microbiota was found to be inconsistent. While higher quantities of Aggregatibacter actinomycetemcomitans, Veillonella parvula, Actinomyces israelii, Capnocytophaga gingivalis and Streptococcus intermedius were reported in siwak users [44], A. actinomyctemcomitans quantities were observed to be lower compared to toothbrush users [34]. Yet recently Rifaey et al. reported that there was no significant difference of $A$. actinomycetemcomitans between siwak and toothbrush user [39].

These observations contradict findings from an in-vitro study which recorded benzyl isothiocyanate (BITC) as the major antibacterial compound of S.persica extract that is responsible to inhibit gram negative bacteria, including A. actinomycetemcomitans, Porphyromonas gingivalis and Streptococcus Mutan [56]. P. gingivalis was the most sensitive to BITC and essential oil, compared to A. actinomycetemcomitans and Haemophilus influenza [57]. Antibacterial activity against gram negative bacteria was highly evidenced in water-based preparation of S.persica extract [58]. Furthermore, periodontal pathogens (Streptococcus mutans, Prevotella intermedia $\mathcal{E}$ Peptostreptococcus and Candida albicans) were significantly sensitive to both water and alcohol extractions [59]. There seems to be a discrepancy in the effects of siwak on the subgingival microbiota between in-vitro and in-vivo study. The reason could be due to unstandardised protocol in preparation of specimen. For instance, there was unmeasured quality of the freshly cut siwak used for everyday toothbrushing in the clinical trials. Instead, the essential oil used in laboratory tests was extracted from the fresh cut of S. persica and standardised to contain the highest concentration of antibacterial compound and produce optimum effects.

The differences in the frequency of siwak practice in the clinical trials may contribute to the inconsistent reports related to the antibacterial effects of siwak [25, 34, 37-39]. According to Albabtain et al. (2018), antibacterial compounds in the siwak brushes reduced significantly from baseline, after being used more than once. The reduction of the same antibacterial compounds was also observed in the saliva, and the compound disappeared after ten minutes [57]. There were several clinical trials that applied the extended duration of siwak brushing than conventional toothbrush practice and this measure should give more chance of getting the benefit from released chemical compounds $[35,36]$.

The quantified microbiota plaque in those studies were collected from subgingival areas of the study participants $[34,39,44]$. These subgingival areas are naturally formed, when the gingival margin is sealed at the cervical of tooth (cementoenamel junction) through junctional epithelium, creating a narrow space between tooth surface [60]. Such anatomical arrangement may limit the mechanical action of siwak and as a result, subgingival plaque remains undisturbed. The architecture of established multispecies community of oral biofilm make them tolerant to antibacterial compound [61], unless an appropriate method, such as by using siwak or any other toothcleaning method is able to remove the subgingival plaque within these areas.

The adverse effect of siwak practice on periodontal health Most of the reported clinical trials did not describe the details of siwak practice, either concerning the technique of tooth cleaning, the duration or the time taken in using the siwak [34, 36, 38, 39]. The lack of information in these studies raises concerns about their reproducibility and may cause any oral health benefits discovered from their research to be deemed as be less meaningful.

Eid and co-workers noted of significant gingival recessions on the labial surface of premolars and central incisors of siwak users [31]. In addition, Baeshen and co-workers also found signs of traumatised tissues on the gingiva. The horizontal toothbrushing is common and easiest to apply, and according to Bergström and coworkers, this method is highly associated with gingival recession and abrasion [62]. The most common method of siwak use observed among users was vertical and/or horizontal directions $[26,31,35,45]$. 
In spite of reductions in plaque, gingivitis and periodontal pocket depth among siwak users, there appears to be more sextants associated with clinical attachment loss [30]. In a case study, one patient presented with severe tooth surface loss on buccal and lingual surfaces, as well as generalised recession, but there was absence of any periodontal pocket. Investigations to locate any etiologic factor prior to restorative treatment suggested that siwak practice may be a probable cause. The patient used the average sized siwak in scrubbing motion on all tooth surfaces, horizontal on buccal and vertical on lingual [45]. Incorrect method of brushing and hard texture of siwak fibers were suspected as the cause of the gingival recession, tooth abrasion and signs of oral soft tissue trauma in long term siwak users [5]. This might explain the higher incidence of gingival recession in populations that use traditional oral hygiene tools such as siwak [23]. It is undeniable that hard bristle contributes to the occurrence gingival recession [63]. Nevertheless, the most important toothbrushing factors that have been associated with the development and progression of gingival recession are frequency and method of brushing [64].

The frequency of toothbrushing in siwak user was between one to five times per day [26, 31], although siwak use may be expected to be at least five times daily or more, based on Islamic religious advice. Siwak is also reported to be frequently used on special days like Friday and during religious special events [16]. The extreme frequency and lengthy oral hygiene practice are secondary influence factors for the development and progression of gingival recession [64]. Recently, a survey among a small group of Muslim siwak users while visited a Mosque in Kuala Lumpur, reported that most of method and siwak practice was according to religious advice [7]. However, the method of siwak practice by Prophet (saw) was not clearly understood in most of Malaysian population [65]. Thus, the instruction on proper method of siwak practice is required with consideration of optimum clinical effectiveness and safety on the oral soft tissues.

Integration of oral hygiene instruction with self-performed mechanical plaque removal is expected to prevent soft tissue trauma and achieve high standard of daily plaque control $[24,66]$. Appropriate oral hygiene education should include knowledge on proper method of siwak practice for existing siwak users and communities of siwak users from different cultures and beliefs. Even among Asian dental educators, knowledge and awareness towards siwak practice is still lacking and this needs to be addressed if proper use of siwak is to be advocated [64].

\section{Conclusion}

This scoping review provides description of the clinical benefit and adverse effect of siwak on periodontal health, based on the evidence of observation and examination among adults. Unmistakeably, evidence-based instructions on safe and effective method and practice of siwak as an oral hygiene tool is still lacking in the literature. The user continues to practice according to their beliefs and there is a risk that improper use may damage oral tissues. To quantitatively measure the effectiveness of intervention and to qualify each included study, systematic reviews and meta-analyses are now required. Furthermore, it is important for future research on oral hygiene instructions for siwak use are developed based on an integrative approach between scientific evidence and cultural considerations.

\section{Abbreviations}

PI: Plaque Index; Gl: Gingivitis Index; BOP: Bleeding on probing; TB: Toothbrush; S: Siwak; OHI-S: Simplified Oral Hygiene Index; PPD: Probing pocket depth; CAL: Clinical attachment loss; REC: Gingival recession; RCT: Randomised controlled trial; DNA: Deoxyribonucleic acid; WHO: World Health Organisation; SPMPR: Self-performed mechanical plaque removal.

\section{Acknowledgements}

The authors acknowledge all the experts that directly and indirectly contribute to data analysis and aligning the defined themes. We express our appreciation to the Deans of the Faculties of Dentistry, Universiti Kebangsaan Malaysia and Universiti Sains Islam Malaysia for their support in the research leading to this publication.

\section{Authors' contributions}

HR has systematically searched the databases, retrieved the articles, implemented the data analysis and prepared the initial draft of the manuscript. TNM has contributed to data analysis and edited the manuscript. SMS has edited the manuscript. All authors read and approved the final manuscript.

\section{Funding}

This project is funded by the Ministry of Higher Education, Malaysia, under the Translational Programme of Malaysian Research University Network (Code: MRUN-RAKAN RU-2019-002/2).

Available of data and materials

The datasets used and/or analysed used in this study are available from the corresponding author on reasonable request.

\section{Declarations}

Ethics approval and consent to participate

Not applicable.

Consent for publication

Not applicable.

Competing interests

The authors declare no competing interests.

\section{Author details}

${ }^{1}$ Department of Family Oral Health, Faculty of Dentistry, Universiti Kebangsaan Malaysia, Jalan Raja Muda Abdul Aziz, 50300 Kuala Lumpur, Malaysia. ${ }^{2}$ Department of Periodontology and Community Oral Health, Faculty of Dentistry, Universiti Sains Islam Malaysia, Pandan Indah, 55100 Kuala Lumpur, Malaysia. ${ }^{3}$ Department of Restorative Dentistry, Faculty of Dentistry, Universiti 
Kebangsaan Malaysia, Jalan Raja Muda Abdul Aziz, 50300 Kuala Lumpur, Malaysia.

Received: 27 August 2021 Accepted: 2 November 2021

Published online: 03 December 2021

\section{References}

1. Ramli H, Halib N, Othman WMNW. Rahsia siwak dalam sunnah dan sains pergigian. Malaysia: USIM Press; 2016. 88 p.

2. Wu CD, Darout IA, Skaug N. Chewing sticks: timeless natural toothbrushes for oral cleansing. J Periodontal Res. 2001;36(5):275-84.

3. Almas K, Al-Lafi TR. The natural toothbrush. World Health Forum. 1995; 16:5.

4. Bos G. The miswak, an aspect of dental care in Islam. Med Hist. 1993;37(1):68-79.

5. Saleh M, Nurhaeni N, Sainuddin O, Abubakar S, Angki J, Sopianah Y, et al. Effect Stick of Miswak on Periodontal Reccesion to Jama'ah Tabligh Kerung Kerung Kota Makassar, Indonesia. Int J Dent Med. 2017;3(1):1-3.

6. Al-Hammadi A, Al-Rabai N, Togoo R, Zakirulla M, Alshahrani I, Alshahrani A. Knowledge, attitude, and behavior related to use of miswak (Chewing Stick): a cross-sectional study from aseer region, Saudi Arabia. Contemp Clin Dent. 2018:9:64-8.

7. Ibrahim AZ, Baharin NH, Asa NM, Ramli H. Influence of Hadiths and Islamic Scholars' opinions on current Miswak practice. Sains Insani. 2020;5(1):101-7.

8. Kalita C, Choudhary B, Saikia AK, Sarma PC. Caries prevalence of schoolgoing boys and girls according to cleaning methods and soft drink-taking frequency in different localities, in and around Guwahati City. J Indian Soc Pedod Prev Dent. 2016;34(3):249-56.

9. Agbor M, Azodo C. Assessment of chewing stick (miswak) use in a Muslim community in Cameroon. Eur J General Dent. 2013;2(1):50-3.

10. Mlenga F, Mumghamba EG. Oral hygiene practices, knowledge, and self-reported dental and gingival problems with rural-urban disparities among primary school children in Lilongwe, Malawi. Int J Dent. 2021;2021:1-10.

11. Al Subait AA, Alousaimi M, Geeverghese A, Ali A, El Metwally A. Oral health knowledge, attitude and behavior among students of age 10-18years old attending Jenadriyah festival Riyadh; a cross-sectional study. Saudi J Dent Res. 2016;7(1):45-50.

12. Baharin NHM, Ibrahim AZ, Asa NM, Ramli H. Assessment of miswak practice among tabligh followers. Int J Bus Econ Law. 2016;11(5):47-52.

13. Odongo CO, Musisi NL, Waako P, Obua C. Chewing-stick practices using plants with anti-streptococcal activity in a Ugandan rural community. Front Pharmacol. 2011:2:13.

14. Raed I, AISadhan KA. Miswak (chewing stick): a cultural and scientific heritage. Saudi Dent J. 1999;11(2):8.

15. FayezNiazi MN, Zohaib K, Zafar MS, Almas K. Role of Salvadora persica chewing stick (miswak): a natural toothbrush for holistic oral health. Eur J Dent. 2016;10:9

16. Alayan HFR, Thomson WM, Foster Page LA, Ibrahim H. The use of Miswak among Muslim immigrants living in New Zealand. NZ Dent J. 2017; 113(2):22-5.

17. Fatin Nur Majdina Nordin SRASM, Bakri MMARMM. The practice of using chewing stick (Salvadora persica) in maintaining oral health: knowledge, perception and attitude of Malaysian Muslims Adult. World Appl Sci J. 2014;30:9.

18. Peters MD, Marnie C, Tricco AC, Pollock D, Munn Z, Alexander L, et al. Updated methodological guidance for the conduct of scoping reviews. JBI Evid Synth. 2020;18(10):2119-26.

19. Tricco AC, Lillie E, Zarin W, O'Brien KK, Colquhoun H, Levac D, et al. PRISMA extension for scoping reviews (PRISMA-SCR): checklist and explanation. Ann Intern Med. 2018;169(7):467-73.

20. Peters MD, Godfrey CM, Khalil H, Mclnerney P, Parker D, Soares CB. Guidance for conducting systematic scoping reviews. JBI Evid Implement. 2015;13(3):141-6.

21. Ercoli C, Caton JG. Dental prostheses and tooth-related factors. J Periodontol. 2018;89:S223-36.

22. World Health Organisation. Consensus statement on oral hygiene. Int Dent J. 2000;50:139.
23. Shah N, Mathur V, Jain V, Logani A, Mathur VP. Association between traditional oral hygiene methods with tooth wear, gingival bleeding, and recession: a descriptive cross-sectional study. Indian J Dent Res. 2018;29(2):150-4

24. Che Musa MF, Ali SM, Mohd FN, Ab HN. Deconstructing orthographic knowledge and cultural awareness of miswak practice amongst dental educators: benefits and barriers: a qualitative study. J Int Oral Health. 2020;12(6):525-31.

25. Al-Otaibi M, Al-Harthy M, Soder B, Gustafsson A, Angmar-Mansson B. Comparative effect of chewing sticks and toothbrushing on plaque removal and gingival health. Oral Health Prevent Dent. 2003;1(4):301-7.

26. Eid MA, Al-Shammery AR, Selim HA. The relationship between chewing sticks (Miswak) and periodontal health, II: relationship to plaque, gingivitis, pocket depth, and attachment loss. Quintessence Int. 1990;21(12):1019-22.

27. Batwa M, Jan B, Sarah B, Meshari FAO. The effectiveness of chewing stick miswak on plaque removal. Saudi Dent J. 2006;18(3):125-33.

28. Shetty RM, Shetty S, Sachin B, Amirisetty R, Agrawal A. Comparative study to assess the effect of chewing stick and toothbrush on oral hygiene and periodontal status among Indian population. Int J Public Health Dent. 2010;1:6-12.

29. Al-Sinaidi AA. Relationships of chronic periodontitis to demographics and self-reported oral hygiene habits in saudi adults. Pak Oral Dent J. 2010;30(2):456-63.

30. Darout IA, Albandar JM, Skaug N. Periodontal status of adult Sudanese habitual users of miswak chewing sticks or toothbrushes. Acta Odontol Scand. 2000;58(1):25-30.

31. Eid MA, Selim HA, Al-Shammery AR. The relationship between chewing sticks (Miswak) and periodontal health, III: relationship to gingival recession. Quintessence Int. 1991;22(1):61-4.

32. Ramadan A, Alshenqiti M. Periodontal status of habitual adult users of miswak sticks or toothbrushes among a population in Al-Madinah AlMunawara. Int J Med Dev Countries. 2021;5(3):865-9.

33. Khawaja SH, Soomro SN, Ali K. Clinical effects of Miswak and tooth brushing on gingivitis. Med Forum. 2019;30(11):4.

34. Al-Otaibi M, Al-Harthy M, Gustafsson A, Johansson A, Claesson R, Angmar-Månsson B. Subgingival plaque microbiota in Saudi Arabians after use of miswak chewing stick and toothbrush. J Clin Periodontol. 2004;31(12):1048-53.

35. Baeshen H, Salahuddin S, Dam R, Zawawi KH, Birkhed D. Comparison of fluoridated miswak and toothbrushing with fluoridated toothpaste on plaque removal and fluoride release. J Contemp Dent Pract. 2017;18(4):300-6

36. Aeeza S, Malik MSS, RasheedAbdur AAQ. Comparative effectiveness of chewing stick and toothbrush: a randomized clinical trial. N Am J Med Sci. 2014;6(7):5

37. Bhambal A, Kothari S, Saxena S, Jain M. Comparative effect of neemstick and toothbrush on plaque removal and gingival health-a clinical trial. J Adv Dental Res. 2011;2(3):51-5.

38. Patel PV, Shruthi S, Kumar S. Clinical effect of Miswak as an adjunct to tooth brushing on gingivitis. J Indian Soc Periodontol. 2012;16(1):84-8.

39. Rifaey N, AlAdwani M, Karched M, Baskaradoss JK. A clinical investigation into the efficacy of miswak chewing sticks as an oral hygiene aid: a crossover randomized trial. Int J Dental Hyg. 2021;19(2):223-30.

40. Othman KFDZY. Therapeutic effects of Salvadora persica (Miswak) on patients with mild to moderate gingivitis. EDJ. 2020;3(2):7.

41. Gazi M, Davies TJ. The immediate-and medium-term effects of Meswak on the composition of mixed saliva. J Clin Periodontol. 1992;19(2):113-7.

42. Darout IA, Skaug N. Comparative oral health status of an adult Sudanese population using miswak or toothbrush regularly. Saudi Dent J. 2004;16(1):29-38.

43. Al-Otaibi M, Angmar-Månsson B. Oral hygiene habits and oral health awareness among urban Saudi Arabians. Oral Health Prev Dent. 2004;2(4):389-96.

44. Darout IA, Skaug N, Albandar JM. Subgingival microbiota levels and their associations with periodontal status at the sampled sites in an adult Sudanese population using miswak or toothbrush regularly. Acta Odontol Scand. 2003;61(2):115-22.

45. Karia R, Kelleher MG. Bizarre tooth surface loss and the miswak stick. Dent Update. 2014:41(4):355-64. 
46. Kumar S, Mangal CRM. A critical review on Salvadora persica: an important medicinal plant of arid zone. Int J Phytomed. 2012;4:12.

47. Ibrahim Idris FA. Prevalence of periodontal diseases among urban and sub-urban 15 years old school children in Khartoum State. Sudan J Oral Health Res. 2016;7(1):9-18.

48. Farsi J, Farghaly M, Farsi N. Oral health knowledge, attitude and behaviour among Saudi school students in Jeddah city. J Dent. 2004;32(1):47-53.

49. Quadri M, Shubayr M, Hattan A, Wafi S, Jafer A. Oral hygiene practices among Saudi Arabian children and its relation to their dental caries status. Int J Dent. 2018. https://doi.org/10.1155/2018/3234970.

50. Al-Tayar BA, Ahmad A, Sinor MZ, Harun MH. Oral health knowledge, attitude, and practices among Yemeni school students. J Int Oral Health. 2019:11(1):15.

51. Peeran SW, Singh AR, Alagamuthu G, Kumar PN. Periodontal status and its risk factors among young adults of the Sebha city (Libya). Dental Res J. 2013;10(4):533-8

52. Nguyen MS, Jagomägi T, Voog-Oras Ü, Nguyen T, Saag M. Oral health behaviour and oral health status of elderly vietnamese. Oral Health Prev Dent. 2018;16(2):153-61.

53. Fiorillo L, Cervino G, Herford AS, Laino L, Cicciù M. Stannous fluoride effects on enamel: a systematic review. Biomimetics. 2020;5(41):1-22.

54. Fiorillo L. Oral health: the first step to well-being. Medicina. 2019;55(676):1-4.

55. Matarese G, Ramaglia L, Fiorillo L, Cervino G, Lauritano F, Isola G. Implantology and periodontal disease: the panacea to problem solving? Open Dent J. 2017;11:460-5.

56. Abier Sofrata FB, Al-Otaibi M, Gustafsson A. Short term clinical effect of active and inactive Salvadora persica miswak on dental plaque and gingivitis. J Ethnopharmacol. 2011;137:5.

57. Albabtain R, Ibrahim L, Bhangra S, Rosengren A, Gustafsson A. Chemical effects of chewing sticks made of Salvadora persica. Int J Dental Hygiene. 2018;16(4):535-40.

58. Abd-Aziz Nadir AAF, Eman AH, Asmaa SI. Miswak (Salvadora persica) roots as antimicrobial and a potential bioactive component. Middle East J Appl Sci. 2020;10(1):7.

59. Siddeegh SPA, Jose M, Pai V. Estimation of antimicrobial properties of aqueous and alcoholic extracts of Salvadora persica (Miswak) on oral microbial pathogens_an invitro study. J Clin Diagn Res. 2016;10(9):F13.

60. Hughes FJ. Chapter 34-periodontium and periodontal disease. In: Vishwakarma A, Sharpe P, Shi S, Ramalingam M, editors. Stem cell biology and tissue engineering in dental sciences. Boston: Academic Press; 2015. p. 433-44.

61. Do T, Devine D, Marsh PD. Oral biofilms: molecular analysis, challenges, and future prospects in dental diagnostics. Clin Cosmet Investig Dent. 2013;5:11.

62. Bergström J, Lavstedt S. An epidemiologic approach to toothbrushing and dental abrasion. Commun Dent Oral Epidemiol. 1979;7(2):57-64.

63. Khocht A, Simon G, Person P, Denepitiya JL. Gingival recession in relation to history of hard toothbrush use. J Periodontol. 1993;64(9):900-5.

64. Heasman PA, Holliday R, Bryant A, Preshaw PM. Evidence for the occurrence of gingival recession and non-carious cervical lesions as a consequence of traumatic toothbrushing. J Clin Periodontol. 2015;42:S237-55.

65. Fatin Nur Majdina Nordin SRASM, Sumaiyah Mohd Tamizi MMAR. A review on the Sunnah of Miswak (Salvadora persica) and its potentiality to improve oral health. Revelat Sci. 2012;2(1):9.

66. Graziani F, Palazzolo A, Gennai S, Karapetsa D, Giuca MR, Cei S, Filice N, Petrini M, Nisi M. Interdental plaque reduction after use of different devices in young subjects with intact papilla: a randomized clinical trial. Int J Dental Hyg. 2018;16(3):389-96.

67. Luna B, Garver KE, Urban TA, Lazar NA, Sweeney JA. Maturation of cognitive processes from late childhood to adulthood. Child Dev 2004;7(5):1357-72.

\section{Publisher's Note}

Springer Nature remains neutral with regard to jurisdictional claims in published maps and institutional affiliations. 